\title{
MAPK inhibitors and siRNAs differentially affect cell death and ROS levels in arsenic trioxide-treated human pulmonary fibroblast cells
}

\author{
WOO HYUN PARK \\ Department of Physiology, Medical School, Research Institute for Endocrine Sciences \\ Chonbuk National University, Jeonju 561-180, Republic of Korea
}

Received November 21, 2011; Accepted January 4, 2012

DOI: $10.3892 /$ or.2012.1661

\begin{abstract}
Arsenic trioxide (ATO; $\mathrm{As}_{2} \mathrm{O}_{3}$ ) induces cell death in various types of cancer cells including lung cancer via increasing reactive oxygen species (ROS) and regulating mitogen-activated protein kinase (MAPK) signaling cascades. However, little is known about the relationship between ATO and MAPK signaling in normal lung cells. Here, we investigated the effects of MAPK inhibitors and siRNAs on ATO-treated human pulmonary fibroblast (HPF) cells in relation to cell growth, cell death, ROS and glutathione (GSH) levels. ATO induced cell growth inhibition and death in HPF cells and it increased ROS levels including $\mathrm{O}_{2}{ }^{-*}$ and GSH depleted cell number. None of the MAPK (MEK, JNK and p38) inhibitors affected cell growth inhibition and cell death by ATO. The MEK inhibitor decreased $\mathrm{O}_{2} \cdot$ levels in ATO-treated HPF cells whereas JNK and p38 inhibitors generally increased ROS levels including $\mathrm{O}_{2}{ }^{-*}$ in these cells. None of these inhibitors altered the ATO-induced GSH depletion. Moreover, ERK siRNA did not change HPF cell growth and
\end{abstract}

Correspondence to: Dr Woo Hyun Park, Department of Physiology, Medical School, Chonbuk National University, Jeonju 561-180, Republic of Korea

E-mail: parkwh71@chonbuk.ac.kr

Abbreviations: HPF, human pulmonary fibroblast; ATO $\left(\mathrm{As}_{2} \mathrm{O}_{3}\right)$, arsenic trioxide; ROS, reactive oxygen species; MMP $\left(\Delta \Psi_{\mathrm{m}}\right)$, mitochondrial membrane potential; NADPH oxidase, nicotine adenine diphosphate oxidase; GPX, GSH peroxidase; TXNR, thioredoxin reductase; SOD, superoxide dismutase; MAPK, mitogen-activated protein kinase; MEK, MAP kinase or ERK kinase; ERK, extracellular signal-regulated kinase; JNK, c-Jun N-terminal kinase; FBS, fetal bovine serum; PI, propidium iodide; H2DCFDA, 2',7'-dichlorodihydrofluorescein diacetate; FITC, fluorescein isothiocyanate; DHE, dihydroethidium; GSH, glutathione; CMFDA, 5-chloromethylfluorescein diacetate; MTT, 3-(4,5-dimethylthiazol-2-yl)-2,5-diphenyltetrazolium bromide; siRNA, small interfering RNA

Key words: HPF, arsenic trioxide, mitogen-activated protein kinase, cell death, reactive oxygen species death by ATO whereas JNK and p38 siRNAs enhanced cell growth inhibition and death. In addition, JNK and p38 siRNAs increased ROS levels and GSH depletion in ATO-treated HPF cells. In conclusion, MAPK inhibitors changed ROS levels in ATO-treated HPF cells, but did not affect cell growth inhibition and death. siRNAs targeting JNK and p38 showing an increase in ROS levels and GSH depletion in ATO-treated HPF cells augmented cell growth inhibition and death.

\section{Introduction}

Reactive oxygen species (ROS) include hydrogen peroxide $\left(\mathrm{H}_{2} \mathrm{O}_{2}\right)$, the superoxide anion $\left(\mathrm{O}_{2}{ }^{\circ}\right)$ and the hydroxyl radical $(\cdot \mathrm{OH})$, which are implicated in many cellular functions such as differentiation, cell proliferation and cell death. They are mainly generated as by-products of mitochondrial respiration or are specifically produced by oxidases, such as nicotine adenine diphosphate (NADPH) oxidase and xanthine oxidase (1). The principal metabolic pathways include superoxide dismutases (SODs), which metabolize $\mathrm{O}_{2} \cdot$ to $\mathrm{H}_{2} \mathrm{O}_{2}$ (2). Further metabolism by catalase or glutathione (GSH) peroxidase (GPX), yields $\mathrm{O}_{2}$ and $\mathrm{H}_{2} \mathrm{O}$ (3). Oxidative stress may result from either overproduction of ROS or accumulation of it.

The mitogen-activated protein kinases (MAPKs) are a family of proteins that transfer signals from the cell membrane to the nucleus in response to different upstream stimuli. Three major groups of MAPKs exist: the extracellular signal regulated kinase (ERK1/2), the c-Jun N-terminal kinase/stress-activated protein kinase (JNK/SAPK) and p38 (4). MAPK signaling pathways are involved in cell proliferation, differentiation and cell death (5). Numerous studies suggest that JNK and p38 are activated by ROS, leading to apoptosis (6-8). ROS can also regulate the activation of the ERK and ERK-activating kinase (MEK) (9). In most instances, MEK-ERK signaling makes a contribution to a pro-survival function rather than a proapoptotic effect (10).

Arsenic trioxide (ATO; $\mathrm{As}_{2} \mathrm{O}_{3}$ ) has long been used as a therapeutic agent for severe diseases including leukemia in East Asia (11). Recently, the antiproliferative effect of ATO has been implicated in a variety of hematological malignancies, especially acute promyelocytic leukemia (APL) $(12,13)$. In addition, there is accumulating evidence that ATO induces 
apoptotic cell death in renal (14), cervical (15) and gastric cancer cells (16). ATO as a mitochondrial poison can induce the collapse of the mitochondrial transmembrane potential (MMP; $\Delta \Psi_{\mathrm{m}}$ ) and, as such, it generates high amounts of ROS (17). ATO also increases ROS levels via the activation of NADPH oxidase (18) or the inhibition of GPX and thioredoxin reductase (TXNR) $(19,20)$. These phenomena can trigger the apoptosis of target cells. In addition, it has been reported that the intracellular GSH content has a decisive effect on ATO-induced apoptosis $(21,22)$. Moreover, the inhibition of MEK/ERK signaling enhances cell death in ATO-treated myeloma and leukemia cells (23-25). ATO-induced apoptosis in cancer cells is related to the activation of JNK (24,26-30) and/or p38 $(27,28)$. On the other hand, it is also reported that blockage of JNK pathway increases ATO-induced apoptosis in human keratinocytes (31) and the inhibition of p38 signaling enhances myeloma cell death by ATO (32).

We recently demonstrated that ATO inhibits the growth of Calu-6 lung cancer cells by inducing cell cycle arrest and apoptosis (33) and MAPK (MEK, JNK and p38) inhibitors slightly intensify cell death in ATO-treated Calu-6 cells (34). However, little is known about the relationship between ATO and MAPK signaling in normal lung cells in relation to ROS. Because we observed that ATO induces the growth inhibition and death in human pulmonary fibroblast (HPF) cells (35), in the present study we investigated the effects of MAPK inhibitors or siRNAs on cell growth, cell death, ROS and GSH levels in ATO-treated HPF cells.

\section{Materials and methods}

Cell culture. Human pulmonary fibroblast (HPF) cells obtained from PromoCell GmbH (Heidelberg, Germany) were maintained in a humidified incubator containing $5 \% \mathrm{CO}_{2}$ at $37^{\circ} \mathrm{C}$. HPF cells were cultured in RPMI-1640 supplemented with $10 \%$ fetal bovine serum (FBS) and $1 \%$ penicillin-streptomycin (Gibco-BRL, Grand Island, NY). HPF cells were used between passages four and eight.

Reagents. ATO was purchased from Sigma-Aldrich Chemical Company (St. Louis, MO) and was dissolved in $1.65 \mathrm{M} \mathrm{NaOH}$ at $100 \mathrm{mM}$ as a stock solution. The MEK (PD98059), JNK (SP600125) and p38 inhibitors (SB203580) obtained from Calbiochem (San Diego, CA) were dissolved in dimethyl sulfoxide (DMSO; Sigma-Aldrich Chemical Company). Cells were pretreated with each MAPK inhibitor for $1 \mathrm{~h}$ before ATO treatment. Based on the previous experiment (36), $10 \mu \mathrm{M}$ of each MAPK inhibitor was used as an optimal dose in this experiment. DMSO $(0.2 \%)$ was used as a control vehicle and it did not alter cell growth or death.

Cell growth assays. Cell growth changes in drug-treated cells were determined by the 3-(4,5-dimethylthiazol-2-yl)-2,5-diphenyltetrazolium bromide (MTT, Sigma-Aldrich Chemical Company) assay as previously described (12). In brief, $3 \times 10^{4}$ cells/well were seeded in 96-well microtiter plates (Nunc, Roskilde, Denmark). After exposure to $50 \mu \mathrm{M}$ ATO in the presence or absence of a given MAPK inhibitor or MAPK-related siRNA duplex for $24 \mathrm{~h}, 20 \mu \mathrm{l}$ of MTT solution [2 $\mathrm{mg} / \mathrm{ml}$ in phosphate-buffered saline (PBS)] were added to each well of the 96-well plates. The plates were incubated for 4 additional hours at $37^{\circ} \mathrm{C}$. Media in plates were withdrawn by pipetting and $200 \mu \mathrm{l}$ of DMSO was added to each well to solubilize the formazan crystals. Optical density was measured at $570 \mathrm{~nm}$ using a microplate reader (SpectraMAX 340, Molecular Devices Co., Sunnyvale, CA).

Annexin-V/PI staining for cell death detection. Apoptosis was determined by staining cells with Annexin-V-fluorescein isothiocyanate (FITC, Ex/Em=488 nm/519 nm; Invitrogen Molecular Probes, Eugene, OR) and propidium iodide (PI, Ex/ Em=488 nm/617 nm; Sigma-Aldrich Chemical Company). In brief, $1 \times 10^{6}$ cells in $60-\mathrm{mm}$ culture dishes (Nunc) were incubated with $50 \mu \mathrm{M}$ ATO in the presence or absence of a given MAPK inhibitor or MAPK-related siRNA duplex for $24 \mathrm{~h}$. Cells were washed twice with cold PBS and then resuspended in $500 \mu \mathrm{l}$ of binding buffer (10 mM HEPES/NaOH pH 7.4, $\left.140 \mathrm{mM} \mathrm{NaCl}, 2.5 \mathrm{mM} \mathrm{CaCl}_{2}\right)$ at a concentration of $1 \times 10^{6}$ cells/ml. Annexin-V-FITC (5 $\mu \mathrm{l})$ and/or PI $(1 \mu \mathrm{g} / \mathrm{ml})$ were then added to these cells, which were analyzed with a FACStar flow cytometer (Becton-Dickinson, Franklin Lakes, NJ).

Measurement of mitochondrial membrane potential [MMP $\left.\left(\Delta \Psi_{m}\right)\right]$. MMP $\left(\Delta \Psi_{\mathrm{m}}\right)$ levels were measured using a rhodamine 123 fluorescent dye (Sigma-Aldrich Chemical Company; Ex/ $\mathrm{Em}=485 \mathrm{~nm} / 535 \mathrm{~nm}$ ) as previously described (37). In brief, $1 \times 10^{6}$ cells in $60-\mathrm{mm}$ culture dish (Nunc) were incubated with $50 \mu \mathrm{M}$ ATO in the presence or absence of a given MAPK inhibitor or MAPK-related siRNA duplex for $24 \mathrm{~h}$. Cells were washed twice with PBS and incubated with rhodamine $123(0.1 \mu \mathrm{g} / \mathrm{ml})$ at $37^{\circ} \mathrm{C}$ for $30 \mathrm{~min}$. The rhodamine 123 staining intensity was determined by flow cytometry (BectonDickinson). Absence of rhodamine 123 from cells indicated the loss of MMP $\left(\Delta \Psi_{\mathrm{m}}\right)$ in HPF cells.

Detection of intracellular $\mathrm{ROS}$ and $\mathrm{O}_{2} \cdot$ levels. Intracellular ROS were detected by means of an oxidation-sensitive fluorescent probe dye, 2',7'-dichlorodihydrofluorescein diacetate $\left(\mathrm{H}_{2} \mathrm{DCFDA}, \mathrm{Ex} / \mathrm{Em}=495 \mathrm{~nm} / 529 \mathrm{~nm}\right.$; Invitrogen Molecular Probes) as previously described (38). $\mathrm{H}_{2}$ DCFDA is poorly selective for superoxide anion radical $\left(\mathrm{O}_{2}{ }^{\circ}\right)$. In contrast, dihydroethidium (DHE, Ex/Em=518 nm/605 nm; Invitrogen Molecular Probes) is a fluorogenic probe that is highly selective for $\mathrm{O}_{2}{ }^{*}$ among the ROS, as previously described (38). Mitochondrial $\mathrm{O}_{2} \cdot$ - levels were detected using the MitoSOX ${ }^{\mathrm{TM}}$ Red mitochondrial $\mathrm{O}_{2}{ }^{*}$ indicator $(\mathrm{Ex} / \mathrm{Em}=510 \mathrm{~nm} / 580 \mathrm{~nm}$; Invitrogen Molecular Probes) as previously described (38). In brief, $1 \times 10^{6}$ cells in 60-mm culture dish (Nunc) were incubated with $50 \mu \mathrm{M}$ ATO in the presence or absence of a given MAPK inhibitor or MAPK-related siRNA duplex for $24 \mathrm{~h}$. Cells were then washed in PBS and incubated with $20 \mu \mathrm{M} \mathrm{H} \mathrm{H}_{2}$ DCFDA, $20 \mu \mathrm{M}$ DHE or $5 \mu \mathrm{M}$ MitoSOX Red at $37^{\circ} \mathrm{C}$ for $30 \mathrm{~min}$. DCF, DHE and MitoSOX Red fluorescence intensities were measured using a FACStar flow cytometer (Becton-Dickinson). ROS and $\mathrm{O}_{2} \cdot$ levels were expressed as mean fluorescence intensity (MFI), which was calculated by the CellQuest software (Becton-Dickinson).

Detection of intracellular glutathione (GSH) levels. Cellular GSH levels were analyzed using a 5-chloromethylfluorescein 
diacetate dye (CMFDA, Ex/Em=522 nm/595 nm; Invitrogen Molecular Probes) as previously described (38). In brief, $1 \times 10^{6}$ cells in $60-\mathrm{mm}$ culture dishes (Nunc) were incubated with $50 \mu \mathrm{M}$ ATO in the presence or absence of a given MAPK inhibitor or MAPK-related siRNA duplex for $24 \mathrm{~h}$. Cells were then washed with PBS and incubated with $5 \mu \mathrm{M}$ CMFDA at $37^{\circ} \mathrm{C}$ for $30 \mathrm{~min}$. The CMF fluorescence intensity was determined using a FACStar flow cytometer (Becton-Dickinson). Negative CMF-stained (GSH-depleted) cells were expressed as the percent of (-) CMF cells.

Transfection of cells with MAPK-related siRNAs. Gene silencing of ERK, JNK and p38 was performed as previously described (39). A non-specific control siRNA duplex [5'-CCUA CGCCACCAAUUUCGU(dTdT)-3'], ERK siRNA duplex [5'-CACCAUUCAAGUUCGACAU(dTdT)-3'], JNK siRNA duplex [5'-CUGGAUAUAGCUUUGAGAA(dTdT)-3'] and p38 siRNA duplex [5'-CAAAUUCUCCGAGGUCUAA (dTdT)-3'] were purchased from the Bioneer Corp. (Daejeon, South Korea). In brief, $2.5 \times 10^{5}$ cells in 6-well plates (Nunc) were incubated in RPMI-1640 supplemented with 10\% FBS. The next day, cells (30-40\% confluence) in each well were transfected with the control or each MAPK siRNA [80 picomole in Opti-MEM (Gibco-BRL)] using Lipofectamine 2000, according to the manufacturer's instructions (Invitrogen, Brandford, CT). One day later, cells were treated with or without $50 \mu \mathrm{M}$ ATO for another $24 \mathrm{~h}$. The transfected cells were collected and used for cell growth analysis, Annexin-VFITC/PI staining, MMP $\left(\Delta \Psi_{\mathrm{m}}\right)$ assessment, and measuremnt of ROS and GSH levels.

Statistical analysis. The results represent the mean of at least three independent experiments (mean $\pm \mathrm{SD}$ ). The data were analyzed using Instat software (GraphPad Software Inc., San Diego, CA). The Student's t-test or one-way analysis of variance (ANOVA) with post hoc analysis using Tukey's multiple comparison test was used for parametric data. Statistical significance was defined as $\mathrm{P}<0.05$.

\section{Results}

Effects of MAPK inhibitors on cell growth and death in ATO-treated HPF cells. We examined the effect of MAPK inhibitors on the growth of ATO-treated HPF cells. For this experiment, $50 \mu \mathrm{M}$ ATO was chosen as a suitable dose to examine the extent of cell growth inhibition and death with or without a given MAPK inhibitor. Based on the MTT assay, $50 \mu \mathrm{M}$ ATO inhibited the growth of HPF cells by about $65 \%$ at $24 \mathrm{~h}$ (Fig. 1). None of MAPK inhibitors affected the growth of ATO-treated HPF cells (Fig. 1). The p38 inhibitor alone increased the growth of HPF control cells (Fig. 1). ATO significantly induced cell death in HPF cells, as evidenced by Annexin-V-FITC staining (Fig. 2A and C). None of the MAPK inhibitors changed the number of Annexin-V staining cells in ATO-treated or -untreated HPF cells (Fig. 2A and C). Furthermore, ATO induced the loss of MMP $\left(\Delta \Psi_{\mathrm{m}}\right)$ in HPF cells (Fig. 2B and D). All the MAPK inhibitors seemed to enhance the loss of MMP $\left(\Delta \Psi_{\mathrm{m}}\right)$ in ATO-treated HPF cells and this effect was statistically significant in the p38 inhibitortreated group (Fig. 2B and D).

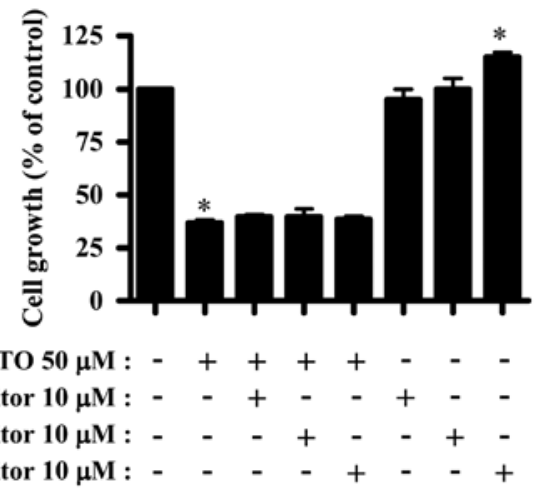

Figure 1. Effects of MAPK inhibitors on cell growth in ATO-treated HPF cells. Exponentially growing cells were treated with $50 \mu \mathrm{M}$ ATO for $24 \mathrm{~h}$ following $1 \mathrm{~h}$ pre-incubation with $10 \mu \mathrm{M}$ MEK, JNK or p38 inhibitor. The graph shows cellular growth changes in HPF cells at $24 \mathrm{~h}$, as assessed by an MTT assay. ${ }^{*} \mathrm{P}<0.05$ compared with the control group.

Effects of MAPK inhibitors on ROS and GSH levels in ATO-treated HPF cells. Next, we determined whether ROS and GSH levels in ATO-treated HPF cells were changed by each MAPK inhibitor. The ROS (DCF) levels were increased in ATO-treated HPF cells (Fig. 3A). While the MEK inhibitor slightly attenuated ROS levels in ATO-treated HPF cells, the p38 inhibitor seemed to increase the ROS levels (Fig. 3A). DHE level reflecting intracellular $\mathrm{O}_{2}^{-*}$ was also increased in ATO-treated HPF cells (Fig. 3B). The MEK inhibitor seemed to decrease $\mathrm{O}_{2}{ }^{-}$level in ATO-treated HPF cells whereas the p38 inhibitor augmented the $\mathrm{O}_{2}{ }^{-}$level (Fig. 3B). p38 inhibitor alone increased ROS levels including $\mathrm{O}_{2}{ }^{-}$in HPF control cells (Fig. 3A and B). Furthermore, MitoSOX Red fluorescence levels, which specifically indicate $\mathrm{O}_{2}{ }^{-}$levels in the mitochondria, were strongly increased in ATO-treated HPF cells (Fig. 3C). The MEK inhibitor decreased mitochondrial $\mathrm{O}_{2} \cdot$ level in ATO-treated HPF cells whereas JNK and p38 inhibitors increased the $\mathrm{O}_{2}{ }^{-}$level (Fig. 3C). The JNK inhibitor decreased mitochondrial $\mathrm{O}_{2}{ }^{-}$levels in control HPF cells (Fig. 3C). In relation to GSH levels, ATO increased the number of GSH depleted cells in HPF cells (Fig. 3D). None of the MAPK inhibitors altered GSH depleted cell number in ATO-treated and -untreated HPF cells (Fig. 3D).

Effects of MAPK-related siRNAs on cell growth and death in ATO-treated HPF cells. Furthermore, it was determined whether MAPK (ERK, JNK and p38)-related siRNAs changed cell growth and death levels in ATO-treated HPF cells. As shown in Fig. 4A, $50 \mu \mathrm{M}$ ATO decreased HPF cell growth about $20 \%$ as compared with control siRNA-treated HPF cells. While ERK siRNA did not affect the growth in ATO-treated HPF cells, JNK and p38 siRNAs intensified the growth inhibition by ATO (Fig. 4A). Treatment with $50 \mu \mathrm{M}$ ATO increased the proportion of Annexin-V-stained cells by at most $10 \%$ as compared with control siRNA-treated HPF cells (Fig. 4B). Probably, the siRNA knockdown system with Lipofectamine 2000 seemed to attenuate the biological activity of ATO. All the MAPK siRNAs did not affect the percentages of Annexin-V-stained cells in HPF control cells for $48 \mathrm{~h}$ (Fig. 4B). JNK and p38 siRNAs enhanced Annexin-V-stained cell number in ATO-treated HPF cells (Fig. 4B). In relation 

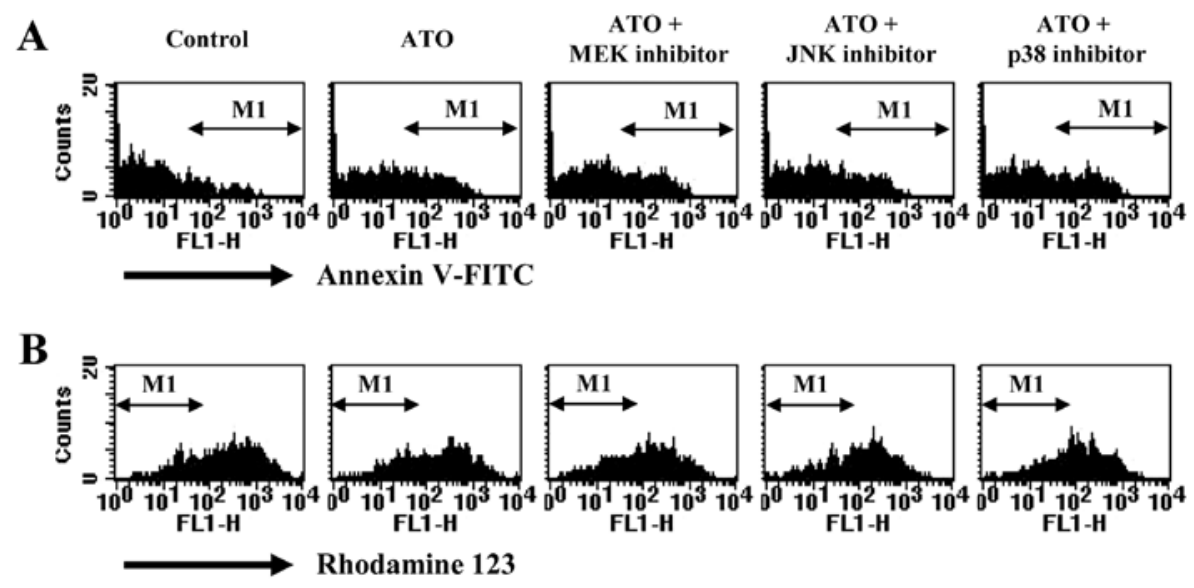

C

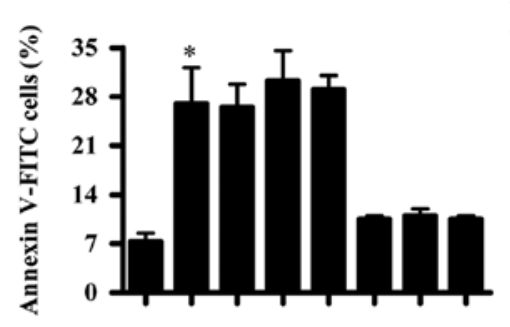

ATO $50 \mu \mathrm{M}:-++++--$ -

MEK inhibitor $10 \mu \mathrm{M}:-\quad-+--+-$

JNK inhibitor $10 \mu \mathrm{M}$ : - - - $-+\quad-\quad+\quad-$

p38 inhibitor $10 \mu \mathrm{M}$ : - $-\quad-\quad+-\quad+$
D

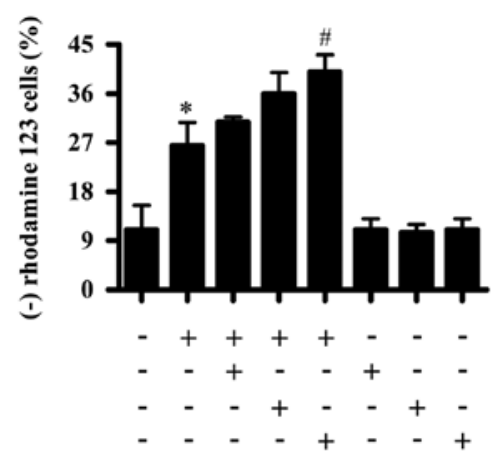

Figure 2. Effects of MAPK inhibitors on cell death and MMP $\left(\Delta \Psi_{\mathrm{m}}\right)$ in ATO-treated HPF cells. Exponentially growing cells were treated with $50 \mu \mathrm{M}$ ATO for $24 \mathrm{~h}$ following $1 \mathrm{~h}$ pre-incubation with $10 \mu \mathrm{M}$ MEK, JNK or p38 inhibitor. Annexin-V-FITC staining and MMP $\left(\Delta \Psi_{\mathrm{m}}\right)$ level in HPF cells were measured with a FACStar flow cytometer. (A and B) Each histogram figure shows representatives for (A) Annexin-V-FITC cells and (B) MMP ( $\left.\Delta \Psi_{\mathrm{m}}\right)$ levels in HPF cells. M1 indicate Annexin-V-FITC-positive cells (A) and MMP $\left(\Delta \Psi_{\mathrm{m}}\right)$ loss cells (B). (C and D) Graphs show the percentages of the M1 regions in (A) and (B), respectively. ${ }^{*} \mathrm{P}<0.05$ compared with the control group. ${ }^{*} \mathrm{P}<0.05$ compared with cells treated with ATO only.

A

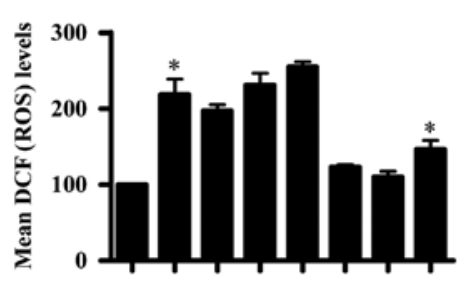

ATO $50 \mu \mathrm{M}:-++++--$

MEK inhibitor $10 \mu \mathrm{M}:--+--+-$

JNK inhibitor $10 \mu \mathrm{M}:--\quad+-\quad+-$

p38 inhibitor $10 \mu \mathrm{M}$ : - $\quad-\quad-\quad+\quad+\quad-+$

C

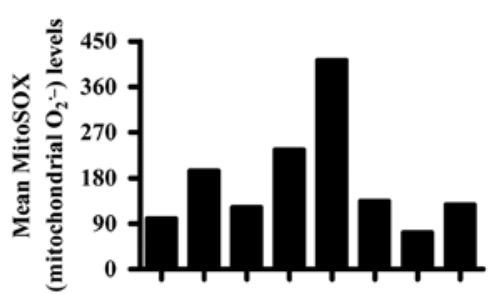

ATO $50 \mu \mathrm{M}:-++++-\quad-$

MEK inhibitor $10 \mu \mathrm{M}$ : - - $+-\quad+-$

JNK inhibitor $10 \mu \mathrm{M}:--\quad+-\quad+$

p38 inhibitor $10 \mu \mathrm{M}$ : - - $-{ }_{-}+-{ }_{-}+$
B

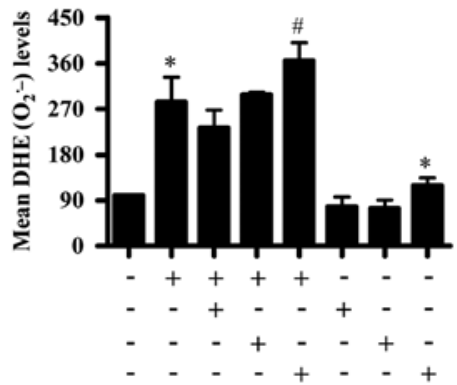

D

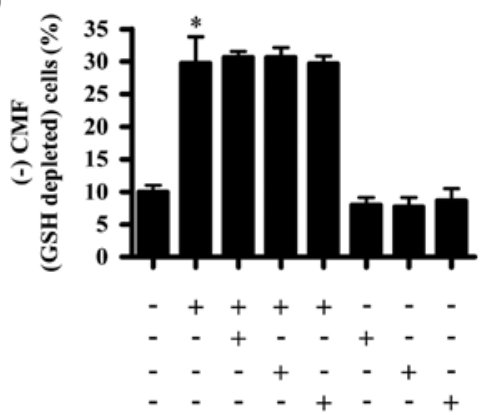

Figure 3. Effects of MAPK inhibitors on ROS and GSH levels in ATO-treated HPF cells. Exponentially growing cells were treated with $50 \mu \mathrm{M}$ ATO for $24 \mathrm{~h}$ following $1 \mathrm{~h}$ pre-incubation of $10 \mu \mathrm{M}$ MEK, JNK or p38 inhibitor. ROS and GSH levels in HPF cells were measured using a FACStar flow cytometer. (A-C) Graphs indicate DCF (ROS) levels (\%) (A), DHE $\left(\mathrm{O}_{2}^{{ }^{\circ}}\right)$ levels $(\%)(\mathrm{B})$ and MitoSOX (mitochondrial $\left.\mathrm{O}_{2}^{{ }^{-}}\right)$levels $(\%)(\mathrm{C})$, as compared with ATO-untreated control cells. (D) The graph shows the percentages of (-) CMF (GSH-depleted) cells. ${ }^{*} \mathrm{P}<0.05$ compared to the control group. ${ }^{\#} \mathrm{P}<0.05$ compared to cells treated with ATO only. 
A

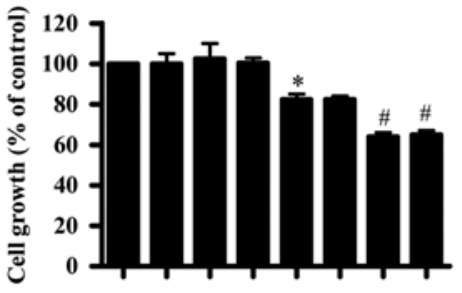

ATO $50 \mu \mathrm{M}$ : - $-\quad-\quad++++$

ERK SIRNA: -+--++-

JNKSIRNA: - $-+\quad-\quad-\quad+\quad-$

p38 SiRNA: - $-\quad+-\quad-+$
B
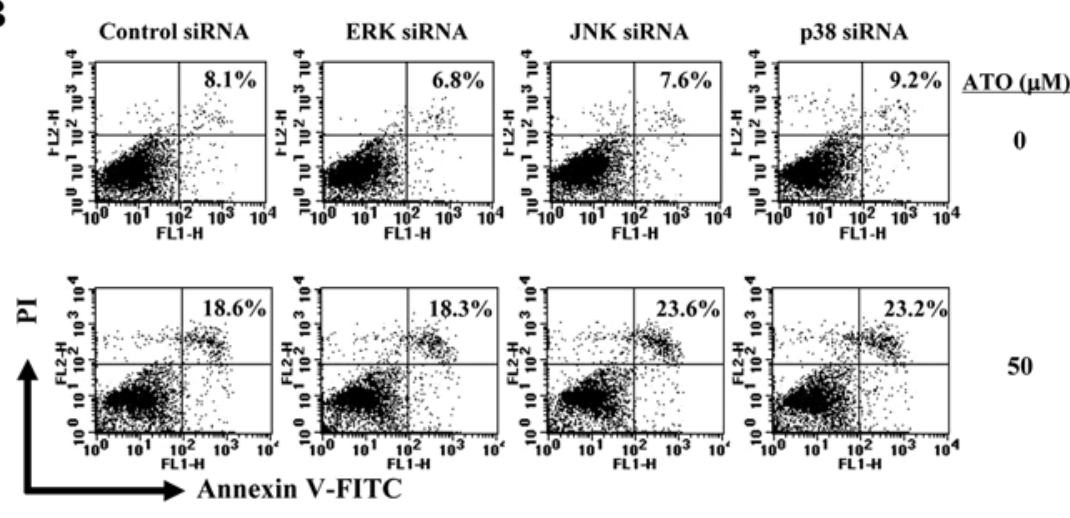

50

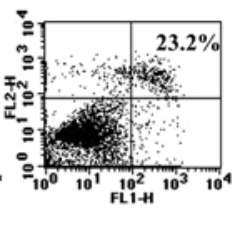

C

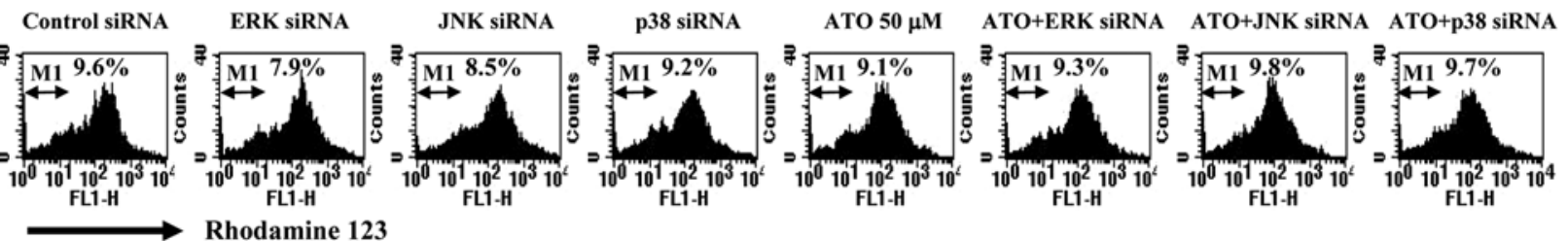

Figure 4. Effects of MAPK siRNAs on cell growth and death in ATO-treated HPF cells. HPF cells ( $\sim 30-40 \%$ confluence) were transfected with either nontarget control siRNA or each MAPK siRNA. One day later, cells were treated with $50 \mu \mathrm{M}$ ATO for additional $24 \mathrm{~h}$. (A) The graph shows cellular growth changes, as assessed by the MTT assay. (B) Annexin-V-FITC and PI-positive cells were measured with a FACStar flow cytometer. The number (\%) in each figure indicates Annexin-V-FITC positive cells regardless of PI negative and positive cells. (C) M1 regions in each histogram indicate MMP $\left(\Delta \Psi_{\mathrm{m}}\right)$ loss as measured with a FACStar flow cytometer and numbers in each histogram demonstrate the percents of M1 regions. " $\mathrm{P}<0.05$ compared with the control group. ${ }^{\text {"P}} \mathrm{P}<0.05$ compared with cells treated with ATO only.

A

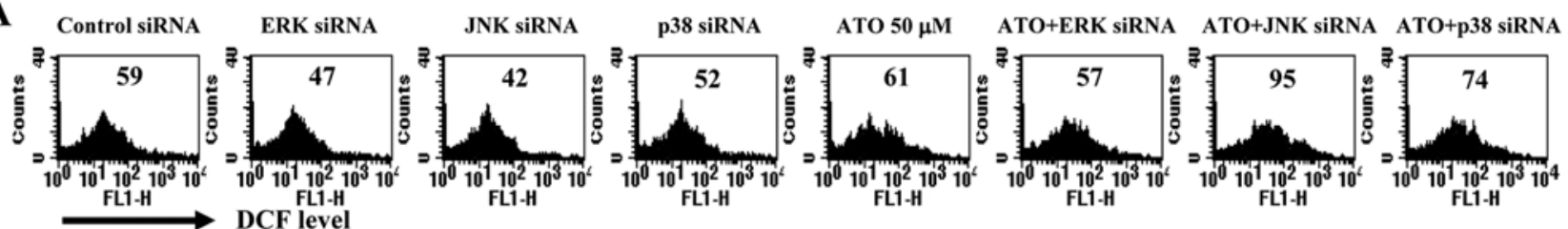

B

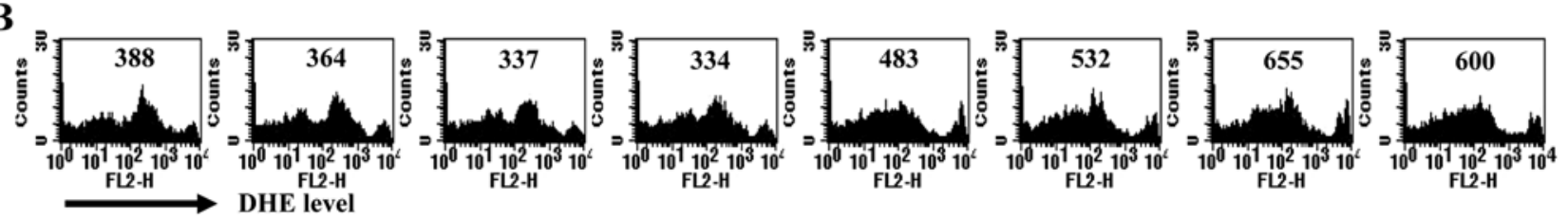

C

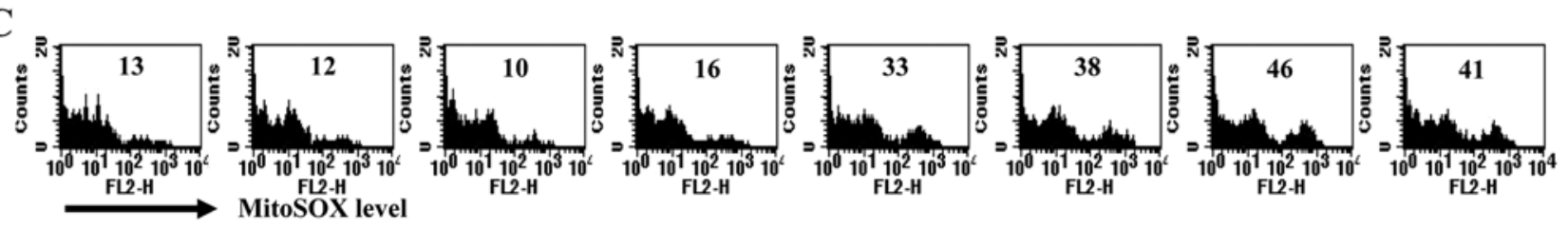

Figure 5. Effects of MAPK siRNAs on ROS levels in ATO-treated HPF cells. HPF cells ( 30 -40\% confluence) were transfected with either non-target control siRNA or each MAPK siRNA. One day later, cells were treated with $50 \mu \mathrm{M}$ ATO for another $24 \mathrm{~h}$. ROS levels in HPF cells were measured using a FACStar flow cytometer. (A-C) Each histogram indicate DCF (ROS) levels (A), DHE $\left(\mathrm{O}_{2}{ }^{-}\right)$levels (B) and MitoSOX (mitochondrial $\mathrm{O}_{2}{ }^{-}$) levels $(\mathrm{C})$. The numbers in each figure indicate mean fluorescence intensity (MFI).

to $\operatorname{MMP}\left(\Delta \Psi_{\mathrm{m}}\right)$, ATO did not induce the loss of MMP $\left(\Delta \Psi_{\mathrm{m}}\right)$ in control siRNA-treated HPF cells and none of the MAPK siRNAs affected the loss of MMP $\left(\Delta \Psi_{\mathrm{m}}\right)$ in ATO-treated or -untreated HPF cells (Fig. 4C).

Effects of MAPK-related siRNAs on ROS and GSH levels in ATO-treated HPF cells. ATO did not increase ROS (DCF) levels in control siRNA-treated HPF cells at $24 \mathrm{~h}$ but it slightly increased $\mathrm{O}_{2}{ }^{-}$level in these cells (Fig. 5A and B). ATO strongly increased mitochondrial $\mathrm{O}_{2}{ }^{-}$levels (Fig. 5C). None of the MAPK siRNAs significantly altered ROS levels including $\mathrm{O}_{2}{ }^{*}$ in HPF cells treated for $48 \mathrm{~h}$, but had a tendency to decrease them (Fig. 5). ERK siRNA did not change ROS (DCF) levels in ATO-treated HPF cells (Fig. 5A), but it slightly increased 


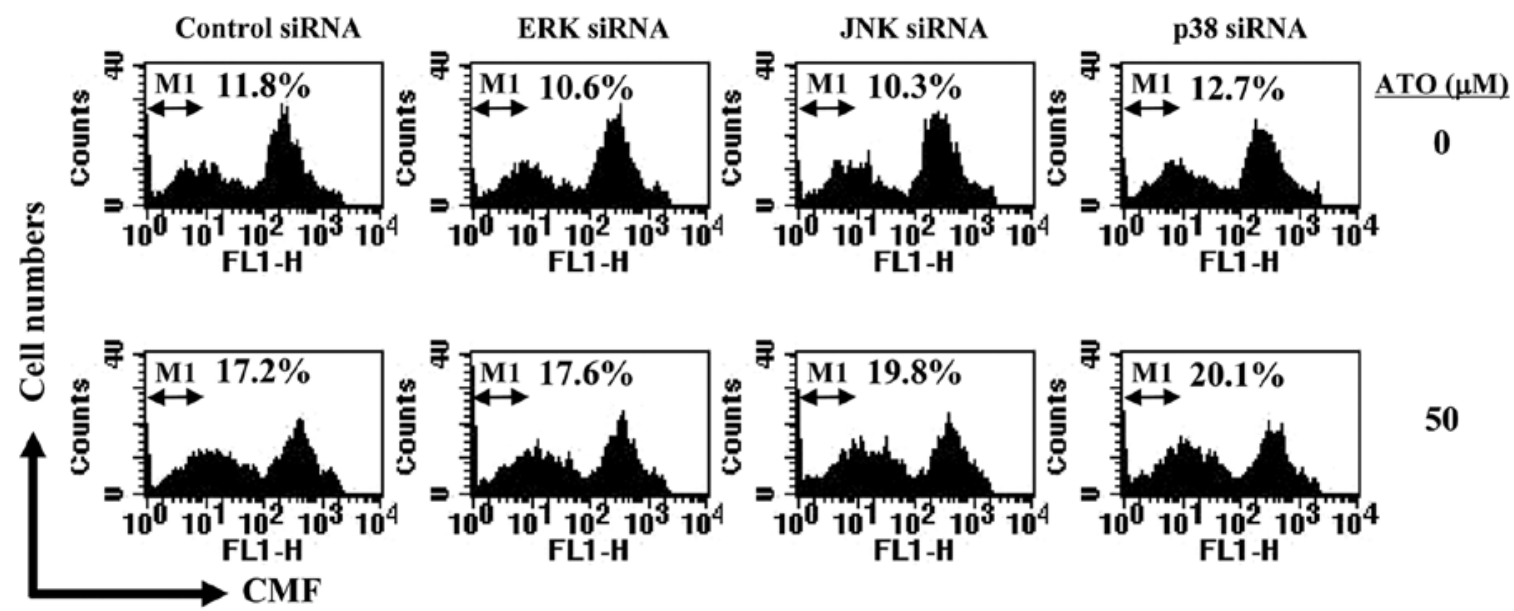

Figure 6. Effects of MAPK siRNAs on GSH levels in ATO-treated HPF cells. HPF cells ( $\sim 30-40 \%$ confluence) were transfected with either non-target control siRNA or each MAPK siRNA. One day later, cells were treated with $50 \mu \mathrm{M}$ ATO for additional $24 \mathrm{~h}$. Each histogram shows CMF (GSH) intensities in HPF cells as measured with a FACStar flow cytometer. M1 regions indicate GSH depletion cells and numbers in each histogram demonstrate the percentages of the M1 regions.

$\mathrm{O}_{2} \cdot$ levels including mitochondrial $\mathrm{O}_{2} \cdot$ in these cells (Fig. 5B and C). Both JNK and p38 siRNAs clearly increased ROS levels including $\mathrm{O}_{2}{ }^{-}$in ATO-treated HPF cells (Fig. 5). Moreover, ATO increased the number of GSH-depleted cells by $~ 5 \%$ as compared with the control siRNA-treated HPF cells (Fig. 6). None of the MAPK siRNAs affected GSH depletion in HPF control cells after $48 \mathrm{~h}$ (Fig. 6). JNK and p38 siRNAs increased GSH depleted cell number in ATO-treated HPF cells (Fig. 6).

\section{Discussion}

In the present study, we demonstrated the effects of MAPK inhibitors or siRNAs on cell growth, cell death, ROS and GSH levels in ATO-treated HPF cells. ATO can induce the failure of MMP $\left(\Delta \Psi_{\mathrm{m}}\right)$, consequently generating high amounts of ROS $(17,40)$. It also increases ROS levels via the activation of NADPH oxidase (18) or the inhibition of GPX and TXNR $(19,20)$. These phenomena can lead to apoptosis in target cells. According to our current results, ATO increased ROS levels including $\mathrm{O}_{2}{ }^{*}$ and induced growth inhibition and death in HPF cells. Furthermore, the loss of MMP $\left(\Delta \Psi_{\mathrm{m}}\right)$ and mitochondrial $\mathrm{O}_{2}{ }^{*}$ levels was strongly increased in ATO-treated HPF cells, implying the possibility that the production of ROS in ATO-treated HPF cells mainly resulted from the disruption of mitochondria.

ERK activation has a pro-survival function rather than pro-apoptotic effects (10). In fact, the inhibition of MEK/ERK signaling enhances cell death in ATO-treated myeloma and leukemia cells (23-25). On the other hand, the MEK inhibitor intensifies growth inhibition and death in the ATO-treated Calu-6 lung cancer cells (34). According to our result, the MEK inhibitor, which presumably decreased ERK activity, did not significantly affect HPF cell growth inhibition and death by ATO. The MEK inhibitor alone did not change HPF growth and death. Furthermore, ERK siRNA did not change HPF cell growth and death by ATO. These results suggested that the inhibition of ERK signaling is not tightly related to cell growth inhibition and death in ATO-treated or -untreated HPF cells. In addition, the MEK inhibitor seemed to decrease ROS levels, especially $\mathrm{O}_{2}{ }^{*}$ in ATO-treated HPF cells whereas ERK siRNA slightly increased $\mathrm{O}_{2}{ }^{-}$level in these cells. The MEK inhibitor and ERK siRNA are likely to differently influence redox states in HPF cells without the alteration of cell growth and death.

It has been reported that ATO-induced apoptosis in cancer cells is related to the activation of JNK $(24,26-30)$ and/or p38 $(27,28)$. In contrast, it is also reported that the blockage of the JNK pathway increases ATO-induced apoptosis in human keratinocytes (31) and that of $\mathrm{p} 38$ signaling enhances myeloma cell death by ATO (32). Similarly, we recently demonstrated that JNK and p38 inhibitors augment growth inhibition and death in the ATO-treated Calu-6 cells (34). According to our current results, both JNK and p38 inhibitors did not affect cell growth and death in ATO-treated HPF cells whereas these siRNAs augmented cell growth inhibition and death in these cells. The p38 inhibitor alone increased HPF control cell growth but its siRNA did not alter the growth. Therefore, different ways in the prevention of JNK and p38 signaling by their inhibitors and siRNAs differently affect cell growth and death in ATO-treated or -untreated HPF cells. These results demonstrate that a pro-survival or pro-apoptotic effect of JNK and p38 signaling in ATO-treated cells is dependent of cell types and/or ways used to block their signaling. Moreover, both inhibitors increased the loss of MMP $\left(\Delta \Psi_{\mathrm{m}}\right)$ in ATO-treated HPF cells without a convincible increase in cell death whereas both siRNAs did not affect the loss in these cells, implying that MMP $\left(\Delta \Psi_{\mathrm{m}}\right)$ loss in HPF cells was not tightly correlated with their cell death.

The JNK and p38 inhibitors seemed to increased ROS levels including mitochondrial $\mathrm{O}_{2} \cdot$ levels in ATO-treated HPF cells. Especially, the p38 inhibitor significantly increased ROS levels in these cells and HPF control cells without influencing the cell death level. On the other hand, JNK or p38 siRNA increased ROS levels in ATO-treated HPF cells, accompanied by an increase in HPF cell death. These results suggest that the changes of ROS levels in ATO-treated or -untreated HPF cells by the JNK and p38 inhibitors or siRNAs are not tightly but at least partially related to HPF cell death. In addition, JNK and p38 inhibitors and their siRNAs differently influence ROS 
levels in these cells. The intracellular GSH content has a decisive effect on ATO-induced apoptosis $(21,22)$. As expected, ATO increased GSH depleted cell number in HPF cells. The MAPK inhibitors did not significantly alter the number of GSH-depleted HPF cells after ATO treatment. JNK and p38 siRNAs showed an enhancement in ATO-induced HPF cell death and increased the GSH-depleted cell number in these cells.

In conclusion, MAPK inhibitors altered ROS levels, but did not affect growth inhibition and death in ATO-treated HPF cells. JNK and p38 siRNAs showing an increase in ROS levels and GSH depletion in ATO-treated HPF cells augmented HPF cell growth inhibition and death. Our present data provide useful information to understand the toxicological effects of ATO on normal lung cells in relation to MAPK signaling and ROS levels.

\section{Acknowledgements}

This research was supported by the Basic Science Research Program through the National Research Foundation of Korea (NRF) funded by the Ministry of Education, Science and Technology (2010-0007059).

\section{References}

1. Zorov DB, Juhaszova $M$ and Sollott SJ: Mitochondrial ROS-induced ROS release: an update and review. Biochim Biophys Acta 1757: 509-517, 2006

2. Zelko IN, Mariani TJ and Folz RJ: Superoxide dismutase multigene family: a comparison of the CuZn-SOD (SOD1), Mn-SOD (SOD2), and EC-SOD (SOD3) gene structures, evolution, and expression. Free Radic Biol Med 33: 337-349, 2002.

3. Wilcox CS: Reactive oxygen species: roles in blood pressure and kidney function. Curr Hypertens Rep 4: 160-166, 2002.

4. Genestra M: Oxyl radicals, redox-sensitive signalling cascades and antioxidants. Cell Signal 19: 1807-1819, 2007.

5. Blenis J: Signal transduction via the MAP kinases: proceed at your own RSK. Proc Natl Acad Sci USA 90: 5889-5892, 1993.

6. Hsin YH, Chen CF, Huang S, Shih TS, Lai PS and Chueh PJ: The apoptotic effect of nanosilver is mediated by a ROS- and JNK-dependent mechanism involving the mitochondrial pathway in NIH3T3 cells. Toxicol Lett 179: 130-139, 2008.

7. Mao X, Yu CR, Li WH and Li WX: Induction of apoptosis by shikonin through a ROS/JNK-mediated process in $\mathrm{Bcr} /$ Abl-positive chronic myelogenous leukemia (CML) cells. Cell Res 18: 879-888, 2008.

8. Gomez-Lazaro M, Galindo MF, Melero-Fernandez de Mera RM, Fernandez-Gomez FJ, Concannon CG, Segura MF, Comella JX, Prehn JH and Jordan J: Reactive oxygen species and p38 mitogenactivated protein kinase activate Bax to induce mitochondrial cytochrome c release and apoptosis in response to malonate. Mol Pharmacol 71: 736-743, 2007.

9. Liu Y, Borchert GL, Surazynski A, Hu CA and Phang JM: Proline oxidase activates both intrinsic and extrinsic pathways for apoptosis: the role of ROS/superoxides, NFAT and MEK/ ERK signaling. Oncogene 25: 5640-5647, 2006.

10. Henson ES and Gibson SB: Surviving cell death through epidermal growth factor (EGF) signal transduction pathways: implications for cancer therapy. Cell Signal 18: 2089-2097, 2006

11. Waxman S and Anderson KC: History of the development of arsenic derivatives in cancer therapy. Oncologist 6 (Suppl 2): 3-10, 2001.

12. Park WH, Seol JG, Kim ES, Hyun JM, Jung CW, Lee CC, Kim BK and Lee YY: Arsenic trioxide-mediated growth inhibition in MC/CAR myeloma cells via cell cycle arrest in association with induction of cyclin-dependent kinase inhibitor, p21, and apoptosis. Cancer Res 60: 3065-3071, 2000.

13. Conrad ME: Treatment of acute promyelocytic leukemia with arsenic trioxide. N Engl J Med 340: 1043-1045, 1999.
14. Hyun Park W, Hee Cho Y, Won Jung C, Oh Park J, Kim K, Hyuck Im Y, Lee MH, Ki Kang W and Park K: Arsenic trioxide inhibits the growth of A498 renal cell carcinoma cells via cell cycle arrest or apoptosis. Biochem Biophys Res Commun 300: 230-235, 2003.

15. Woo SH, Park IC, Park MJ, Lee HC, Lee SJ, Chun YJ, Lee SH, Hong SI and Rhee $\mathrm{CH}$ : Arsenic trioxide induces apoptosis through a reactive oxygen species-dependent pathway and loss of mitochondrial membrane potential in HeLa cells. Int J Oncol 21: 57-63, 2002.

16. Zhang TC, Cao EH, Li JF, Ma W and Qin JF: Induction of apoptosis and inhibition of human gastric cancer MGC-803 cell growth by arsenic trioxide. Eur J Cancer 35: 1258-1263, 1999.

17. Miller WH Jr, Schipper HM, Lee JS, Singer J and Waxman S: Mechanisms of action of arsenic trioxide. Cancer Res 62: 3893 3903, 2002.

18. Chou WC, Jie C, Kenedy AA, Jones RJ, Trush MA and Dang CV: Role of NADPH oxidase in arsenic-induced reactive oxygen species formation and cytotoxicity in myeloid leukemia cells. Proc Natl Acad Sci USA 101: 4578-4583, 2004.

19. Lu J, Chew EH and Holmgren A: Targeting thioredoxin reductase is a basis for cancer therapy by arsenic trioxide. Proc Natl Acad Sci USA 104: 12288-12293, 2007.

20. Chouchane $S$ and Snow ET: In vitro effect of arsenical compounds on glutathione-related enzymes. Chem Res Toxicol 14: 517-522, 2001.

21. Wu XX, Ogawa O and Kakehi Y: Enhancement of arsenic trioxide-induced apoptosis in renal cell carcinoma cells by L-buthionine sulfoximine. Int J Oncol 24: 1489-1497, 2004.

22. Dai J, Weinberg RS, Waxman S and Jing Y: Malignant cells can be sensitized to undergo growth inhibition and apoptosis by arsenic trioxide through modulation of the glutathione redox system. Blood 93: 268-277, 1999.

23. Lunghi P, Giuliani N, Mazzera L, Lombardi G, Ricca M, Corradi A, Cantoni AM, Salvatore L, Riccioni R, Costanzo A, et al: Targeting MEK/MAPK signal transduction module potentiates ATO-induced apoptosis in multiple myeloma cells through multiple signaling pathways. Blood 112: 2450-2462, 2008.

24. Ramos AM, Fernandez C, Amran D, Esteban D, de Blas E, Palacios MA and Aller P: Pharmacologic inhibitors of extracellular signal-regulated kinase (ERKs) and c-Jun NH(2)-terminal kinase (JNK) decrease glutathione content and sensitize human promonocytic leukemia cells to arsenic trioxide-induced apoptosis. J Cell Physiol 209: 1006-1015, 2006.

25. Lunghi P, Tabilio A, Lo-Coco F, Pelicci PG and Bonati A: Arsenic trioxide (ATO) and MEK1 inhibition synergize to induce apoptosis in acute promyelocytic leukemia cells. Leukemia 19: 234-344, 2005.

26. Potin S, Bertoglio $\mathrm{J}$ and Breard $\mathrm{J}$ : Involvement of a Rho-ROCK-JNK pathway in arsenic trioxide-induced apoptosis in chronic myelogenous leukemia cells. FEBS Lett 581: 118-124, 2007.

27. Kang YH and Lee SJ: Role of p38 MAPK and JNK in enhanced cervical cancer cell killing by the combination of arsenic trioxide and ionizing radiation. Oncol Rep 20: 637-643, 2008.

28. Kang YH and Lee SJ: The role of p38 MAPK and JNK in Arsenic trioxide-induced mitochondrial cell death in human cervical cancer cells. J Cell Physiol 217: 23-33, 2008.

29. Davison K, Mann KK, Waxman S and Miller WH Jr: JNK activation is a mediator of arsenic trioxide-induced apoptosis in acute promyelocytic leukemia cells. Blood 103: 3496-3502, 2004.

30. Kajiguchi T, Yamamoto K, Hossain K, Akhand A A, Nakashima I, Naoe T, Saito H and Emi N: Sustained activation of c-jun-terminal kinase (JNK) is closely related to arsenic trioxideinduced apoptosis in an acute myeloid leukemia (M2)-derived cell line, NKM-1. Leukemia 17: 2189-2195, 2003.

31. Huang HS, Liu ZM and Hong DY: Blockage of JNK pathway enhances arsenic trioxide-induced apoptosis in human keratinocytes. Toxicol Appl Pharmacol 244: 234-241, 2010.

32. Wen J, Cheng HY, Feng Y, Rice L, Liu S, Mo A, Huang J, Zu Y, Ballon DJ and Chang CC: P38 MAPK inhibition enhancing ATO-induced cytotoxicity against multiple myeloma cells. Br J Haematol 140: 169-180, 2008.

33. Han YH, Kim SZ, Kim SH and Park WH: Arsenic trioxide inhibits the growth of Calu- 6 cells via inducing a G2 arrest of the cell cycle and apoptosis accompanied with the depletion of GSH. Cancer Lett 270: 40-55, 2008. 
34. Han YH, Moon HJ, You BR, Kim SZ, Kim SH and Park WH: The effect of MAPK inhibitors on arsenic trioxide-treated Calu-6 lung cells in relation to cell death, ROS and GSH levels. Anticancer Res 29: 3837-3844, 2009.

35. Han YH, Moon HJ, You BR, Kim SZ, Kim SH and Park WH: Effects of arsenic trioxide on cell death, reactive oxygen species and glutathione levels in different cell types. Int J Mol Med 25: 121-128, 2010.

36. Han YH, Moon HJ, You BR, Kim SZ, Kim SH and Park WH: JNK and p38 inhibitors increase and decrease apoptosis, respectively, in pyrogallol-treated calf pulmonary arterial endothelial cells. Int J Mol Med 24: 717-722, 2009.

37. Han YH, Kim SZ, Kim SH and Park WH: Arsenic trioxide inhibits growth of As4.1 juxtaglomerular cells via cell cycle arrest and caspase-independent apoptosis. Am J Physiol Renal Physiol 293: F511-F520, 2007.
38. Han YH, Kim SH, Kim SZ and Park WH: Caspase inhibitor decreases apoptosis in pyrogallol-treated lung cancer Calu- 6 cells via the prevention of GSH depletion. Int J Oncol 33: 1099-1105, 2008.

39. Elbashir SM, Harborth J, Lendeckel W, Yalcin A, Weber K and Tuschl T: Duplexes of 21-nucleotide RNAs mediate RNA interference in cultured mammalian cells. Nature 411: 494-498, 2001.

40. Kim HR, Kim EJ, Yang SH, Jeong ET, Park C, Kim SJ, Youn MJ, So HS and Park R: Combination treatment with arsenic trioxide and sulindac augments their apoptotic potential in lung cancer cells through activation of caspase cascade and mitochondrial dysfunction. Int J Oncol 28: 1401-1408, 2006. 